
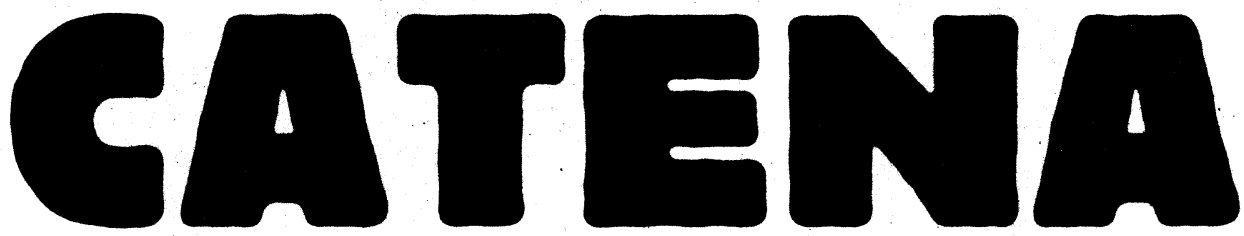

AN INTERDISCIPLINARY JOURNAL OF

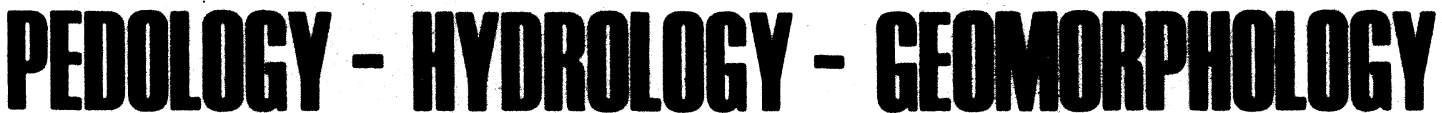

INTERDISZIPLINARE ZEITSCHRIFT FÜR

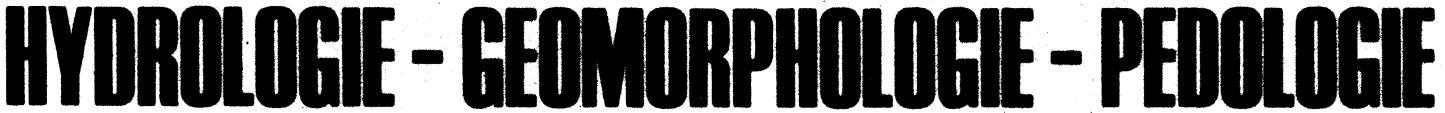

JOURNAL INTERDISCIPLINAIRE DE
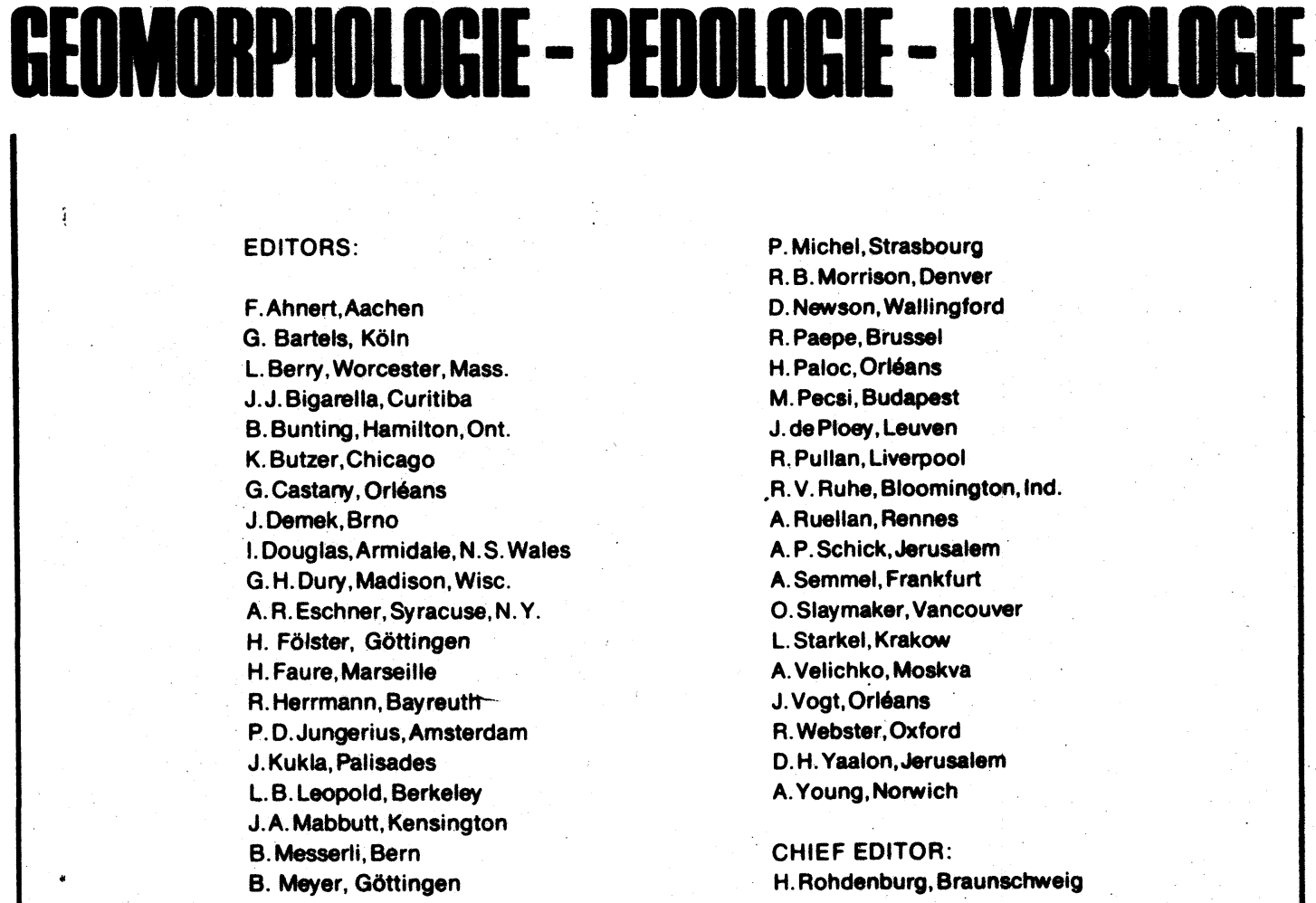

P. Michel, Strasbourg

R. B. Morrison, Denver

D. Newson, Wallingford

R.Paepe, Brussel

H.Paloc, Orléans

M.Pecsi, Budapest

J. de Ploey, Leuven

R.Pullan, Liverpool

R. V. Ruhe, Bloomington, Ind.

A. Ruellan, Rennes

A.P.Schick, Jerusalem

A.Semmel, Frankfurt

O.Slaymaker, Vancouver

L. Starkel, Krakow

A. Velichko, Moskva

J.Vogt, Orléans

R. Webster, Oxford

D.H.Yaalon, Jerusalem

A. Young, Nonwich

CHIEF EDITOR:

H.Rohdenburg, Braunschweig 


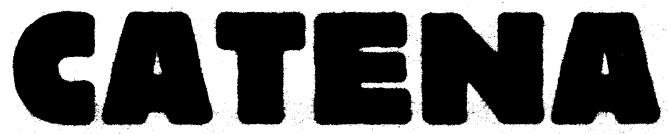

\begin{abstract}
AN INTERDISCIPLINARY JOUANAL OF PEDOLOGY - HYDROLOGY - GEOMOAPHOLOGY INTERDISZIPLINARE ZEITSCHAIFT FOA HYOAOLOGIE - GEOMOAPHOLOQIE - PEDOLOGIE JOURNAL INTERDISCIPLINAIAE DE GEOMORPHOLOGIE - PEDOLOGIE - HYOROLOGIE
\end{abstract}

\title{
GUIDE FOR AUTHORS
}

The title, CATENa, is chosen to represent the connections between different disciplines which the fournal will seek to make. At the same time it symbolizes an attempt to unite scientists of different nations, modes of thought and, not least, different languages.

The editors of Camana take the view that the emphasis on interdisciplinary aspects of PEDOLOGY, HYDROLOCY, GEOWORPBOLOGY and the related aspects of GBOLOGY, CLIMATOLOGY and the BIOLOGICAL sCIENCES can contribute to the advancement of these disciplines in their own right, as well as relating them to each other. Certainiy there are at the present large gaps between specialisms, which it is worth attempting to fill.

CATENA publishes original research, reviews of research flelds, and critlcal comentaries on particular articles or themes. Review sections will not seek complete coverage, but will indicate publications of particular importance in relation to its chosen interdisciplinary fields.

Publication detalls

1. Sultable manuscripts will be published as rapidiy as possible (4 - 6 months). The printing time will be reduced to the minimum required by technical necessities.

2. There is no general rule regarding length of manuscripts. However, general preference will be given to manuscripts of wedium length (10 - 15000 words).

3. In order to meet these requirements, it is intended that there should be flexibility with respect to publication dates. Individual 1 ssues will be of varying length, depending on manuscripts offered. These will be grouped into continuously paginated volumes with a length of 400 - 450 pages.

In order to avold delay in publication, manuscripts must conform with the directions outlined below. Manuscripts inadequately prepared will be returned to the author (s). Manuscripts will be revlewed by two editors (one of whom way be chosen by the author) regarding the following polnts: title, sumary, length, arrangewent and content of the text, adequate documentation, soundness of interpretations and conclusions as justified by the data, language standard, 12lustrations, bibliography.

Manuscripts should be send to:

either a) one copy to an editor of free cholce, and two coples to the Editorial office (stating the name of editor already in possession of the third copy)

or b) directly to the Editorial office in triplicate.

In case of several authors all correspondence will be wade with the person submitting the manuscript.

The originals of manuscript, figures and photos should be sent to the Editorial office; illustrations for the second and third wanuscripts can be copies.

Manuscripts should be arxanged in this sequence:

a) Title

b) Author (s)

c) Summary

d) Zusammenfassung (Cerman) or Rosume (French)

e) Contents

f) List of 1llustrations $f$ in more voluminous papers only

g) Text

h) Bibllography

On title page: title of article, author (s), affiliation(s), complete adress (es).

All essays wust have an English sumary containing essential results.

English papers: Summary + Resumb or zusammenfassung

French papers: Sumary + Resumb

German papers: Sumary + zusamenfassung

Additional sumaries in other languages can be printed. Translations of sumaries into

German can be provided by the Editorial office. 


\title{
C A T E N A \\ VOL. $5,145-149$ \\ BRAUNSCHWEIG 1978
}

\section{RADIOCARBON CHRONOLOGY OF LATE QUATERNARY LAKES IN THE KALAHARI, SOUTHERN AFRICA}

\author{
K. Heine \\ Geographisches Institut der Rheinischen Friedrich-Wilhelms-Universität \\ Franziskanerstraße 2, D-5300 Bonn 1, Bundesrepublik Deutschland \\ (manuscript accepted for publication June 12, 1978)
}

\section{SUMMARY}

Some radiocarbon dates concerning the late Quaternary development of the southern Kalahari and the Ngami-Makgadikgadi area are given. The southern Kalahari is characterized by pluvial conditions during the last glacial maximum (ca. 19,000 to $12,000 \mathrm{yr}$ b.p.) and relatively arid conditions during the Holocene and before ca. 19,000 yr b.p.. A very high lake level in the Makgadikgadi depression occurred during ca. 30,000 to 19,000 yr b.p.; here the last glacial maximum was arid; a second pluvial period with less high lake levels is dated ca. 12,000 yr b.p.. Minor fluctuations of the Makgadikgadi lake level eventually occurred during the Early Holocene. The preliminary chronostratigraphy is shown in table 1.

\section{ZUSAMMENFASSUNG}

Einige ${ }^{14} \mathrm{C}$-Daten zur spätquartären Entwicklung der südlichen Kalahari und des Ngami-Makarikari-Gebietes werden vorgestellt. Die südliche Kalahari wird durch pluviale Bedingungen während des letzten Hochglazials (ca. 19000 bis 12000 B.P.) und durch relativ aride Bedingungen während des Holozäns und vor ca. 19000 B.P. charakterisiert. In der Makarikari-Depression bestand ein sehr hoher Seespiegel während ca. 30000 bis 19000 B.P.; hier war das letzte Hochglazial arid; eine zweite pluviale Phase mit weniger hohem Seespiegel wird auf ca. 12000 B.P. datiert. Geringere Fluktuationen des Makarikari-Seespiegels gab es vermutlich im Frühholozän. Eine vorläufige Chronostratigraphie wird in Tabelle 1 wiedergegeben.

The recent increase in observational evidence for late Quaternary moist periods in North Africa, East Africa, Arabia, and Australia (ROGNON \& WILLIAMS 1977, BUTZER et a1. 1972, GASSE 1977, MCCLURE 1976, BOWLER 1975), derived largely from dating and analysis of lake sediments, has been accompanied by little attention on fossil lake beds in the Kalahari of southern Africa, although fossil lakes have long been known to exist in the Kalahari region (PASSARGE 1904, JAEGER 1939, LANCASTER 1974). The results of a preliminary attempt to establish the age of a series of late Quaternary sediments and fluvial deposits in the Kalahari region are reported here.

The Kalaharian zone is situated on a plateau generally more than 1,000 $\mathrm{m}$ above sea level in Botswana, eastern South West Africa (Namibia), and north western Transvaal, stretching from the Okavango River in the north to close to the Orange River in the Republic of South Africa in the south (Fig. 1). It is flat or gently undulating, with sand dunes more frequently occurring in the south west. The true Kalahari os a huge sand-filled basin (DE VOS 1975). The zone is semi-arid. Rain- 


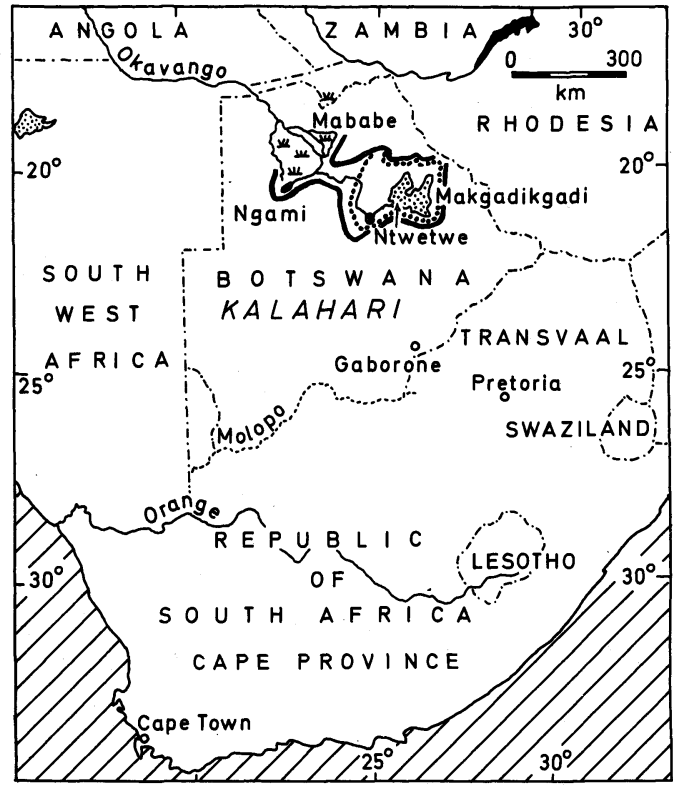

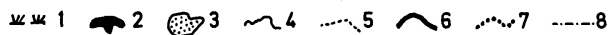

Fig. 1: Location map of places mentioned in the text. 1, Swamp; 2, Lake; 3, Pan; 4, Perennial river; 5, Valley with episodical run-off; 6, Fossil lake shore during the most extensive late Quaternary transgressive phase; 7, Minor fossil lake shore; 8, International border.

main generations of lake beds in the Ngami-Okavango-Makgadikgadi region. The older lake may on one or more occasions have formed a very large and continuous body of water with the Okavango-Mababe-Ngami depression (GREY \& COOKE 1977), estimated to have been about $60,000 \mathrm{~km}^{2}$ in area. Aeolian sands antedate the sediments of the younger lake. The 'contouring' of the slopes of dunes of the Ntwetwe pan in the Makgadikgadi is believed to have been caused by the retreating waters of the younger lake that flooded the pan after the formation of the dunes (GROVE 1969).

In the southern Kalahari the fossil bearing fluvial deposits of the Molopo River are underlain by aeolian sands; modern dune sands of light colour cover the fluvial sediments of the valleys, whereas the sand ridges of the neighbouring areas show the bright red colour which is characteristic of the Kalahari dunes.

Radiocarbon dating of the lake beds from the Ngami-Makgadikgadi basins and of the fluvial sediments of the Molopo supports the hypothesis that two main periods of high water level occurred in the northern and middle Kalahari during the late Quaternary whereas the southern Kalahari is characterised by only one pluvial period (Table 1). In the tropical part of the Kalahari the dates place the first pluvial lake between 31,000 (or older) and 19,000 yr b.p., and the different stages of the second pluvial lake between ca. 12,000 and 9,000 yr b.p. (and younger). An arid period between ca. 19,000 and 12,000 yr b.p. separates the two pluvial lakes. In the subtropical southern part of the Kalahari as well as in the Cape province (VAN ZINDEREN BAKKER 1976) the period between ca. 19,000 and 12,000 yr b.p. shows fairly wet climatic conditions (pluvial). 
Table 1: THE MAIN STAGES IN THE LATE QUATERNARY EVOLUTION OF THE NGAMI-MAKGADIKGADI BASINS AND THE MOLOPO RIVER VALLEY

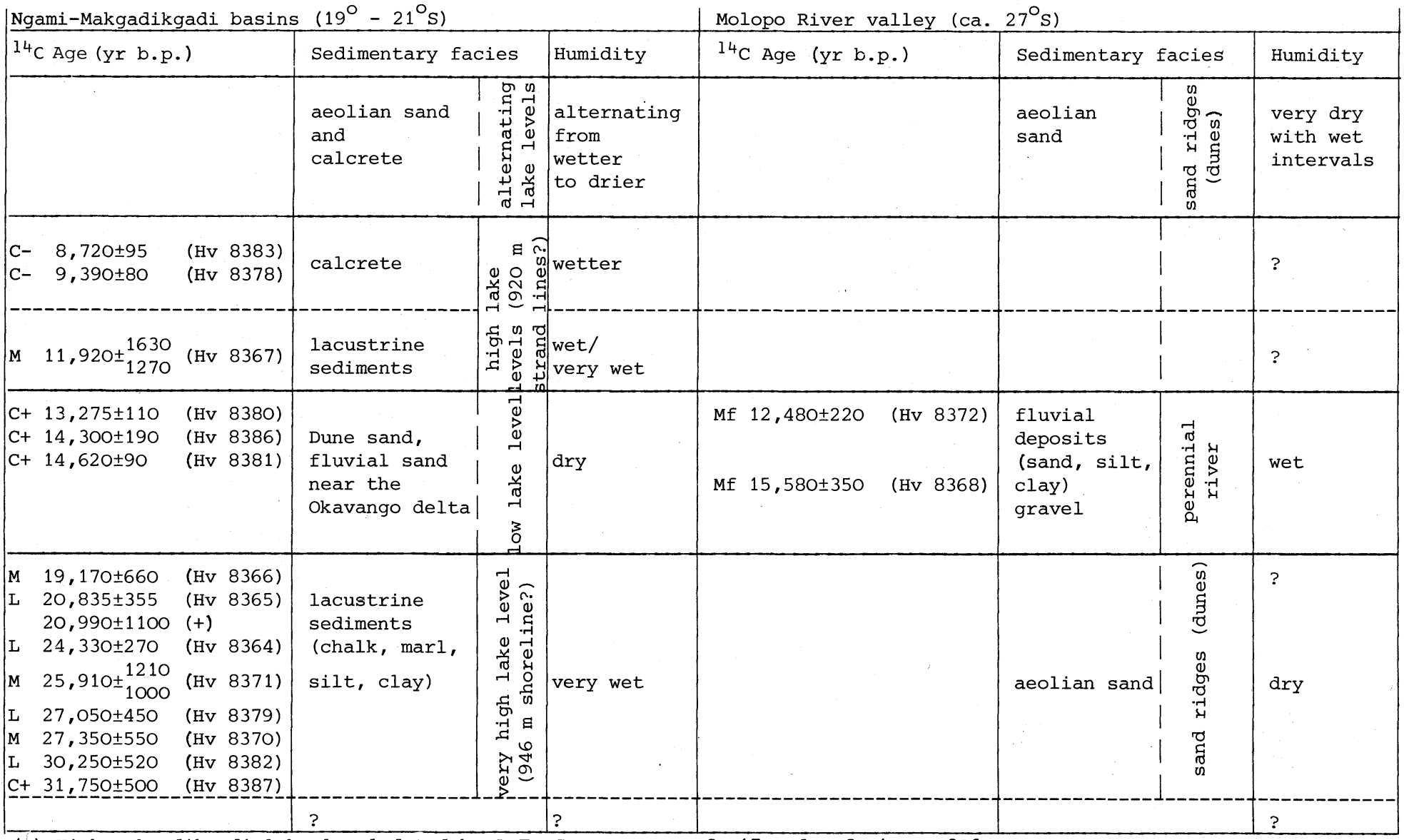

(+) High Makgadikgadi lake level dated by A.T. Grove, see ref. 17 and ref. 1, p. 306.

L Lacustrine chalk, indicating high lake level.

M Mollusca, indicating high lake level and/or fresh water supply.

Mf Mollusca, indicating a perennial river.

C- Calcrete without fossil calcite fragments.

C+ Calcrete with fossil calcite fragments; the ${ }^{14} \mathrm{C}$ determination does not represent the true age of the calcrete formation 
The preliminary chronostratigraphy (Table 1 ) confirms the assumption that the major environmental changes along the temperate and tropical margins of the Kalahari seem to be in phase with the variations in precipitation and evaporation in North and East Africa as well as in Arabia and Australia. Variations in temperature seem to be synchroneous worldwide; variations in humidity depend on a shifting of the climatic belts during the late Quaternary and therefore do not occur synchroneously in various regions of southern Africa. In the Kalaharian zone, as in North and East Africa, Arabia, Australia, and Mexico (HEINE 1974, 1977), we have to distinguish between the following periods with different climatic conditions: (1) the high glacial period $(19,000$ to $12,000 \mathrm{yr}$ b.p.) characterised by a cool and arid climate in the northern, western, middle, and eastern Kalahari and a cold and humid climate (winter rains) in the southern Kalahari, (2) the interstadial period $(\geq 31,000$ - 19,000 yr b.p.) and the late Pleistocene/early Holocene (12,000 9,000 yr b.p.), both periods are characterised by pluvials in the Kalahari, and (3) the postglacial period ( $<9,000 \mathrm{yr}$ b.p. = Holocene) with a warm and semihumid climate (tropical summer rains) in the northern, western, middle, and eastern Kalahari and a warm and semi-arid climate (subtropical anticyclone) in the southern Kalahari.

\section{ACKNOWLEDGEMENTS}

These investigations were sponsored by the DEUTSCHE FORSCHUNGSGEMEINSCHAFT. Special acknowledgement is due to Professor Dr. M.A. GEYH (Hannover) for radiocarbon dating and to Professor Dr. R. HUCKRIEDE (Marburg) for palaeontological determinations of shells and snails.

\section{BIBLIOGRAPHY}

BOWLER, J.M. (1975): Deglacial Events in Southern Australia: Their Age, Nature, and Palaeoclimatic Significance. Quaternary Studies, The Royal Society of New Zealand, Bul1. 13, 75 - 82, Wellington.

BUTZER, K.W., ISAAC, G.L., RICHARDSON, J.L. \& WASHBOURN-KAMAU, C. (1972): Radiocarbon dating of East African lake levels. Science 175, $1069-1076$.

COLE, M.M. \& BROWN, R.C. (1976): The vegetation of the Ghanzi area of western Botswana. Journal of Biogeography 3, $169-196$.

DE VOS, A. (1975): Africa, the Devastated Continent? W. Junk, The Hague.

DIEM, M. (1977): Ein weiträumiger extremer Regenfall in der Kalahari. Meteorologische Rundschau 30, 138 - 144.

GASSE, F. (1977): Evolution of Lake Abhé (Ethiopia and TFAI), from 70,000 b.p. Nature 265, $42-45$.

GREY, D.R.C. \& COOKE, H.J. (1977): Some Problems in the Quaternary Evolution of the Landforms of Northern Botswana. Catena 4, 123 - 133.

GROVE, A.Z. (1969): Landforms and Climate in the KaTahari and Ngamiland. The Geographical Journal 135, 191 - 212.

HEINE, K. (1974): Bemerkungen zu neueren chronostratigraphischen Daten zum Verhältnis glazialer und pluvialer Klimabedingungen. Erdkunde 28, $303-312$.

HEINE, K. (1977): Beobachtungen und überlegungen zur eiszeitlichen Depression von Schneegrenze und Strukturbodengrenze in den Tropen und Subtropen. Erdkunde $31,161-178$.

JAEGER, F. (1939): Trockenseen der Erde. Petermanns Mitteilungen Erg.H. 236, 1-159.

LANCASTER, I.N. (1974): Pans of the Southern Kalahari. Botswana Notes and Records $\underline{6}, 157-169$.

MCCLURE, H.A. (1976): Radiocarbon chronology of late Quaternary lakes in the Arabian Desert. Nature 263, $755-756$.

PASSARGE, S. (1904): Die Kalahari. D. Reimer, Berlin. 
ROGNON, P. \& WILLIAMS, M.A.J. (1977): Late Quaternary Climatic Changes in Austra1 ia and North Africa: A Prel iminary Interpretation. Palaeogeography, Palaeocl imatology, Palaeoecology 21, 285 - 327.

STREET, F.A. \& GROVE, A.T. (1976): Environmental and climatic implications of late Quaternary lake-level fluctuations in Africa. Nature 261, $385-390$.

VAN ZINDEREN BAKKER, E.M. (1976): The Evolution of Late-Quaternary Palaeoclimates of Southern Africa. Palaeoecology of Africa 9, $160-202$.

VERHAGEN, B.Th., MAZOR, E. \& SELLSCHOP, J.P.F. (1974): Radiocarbon and tritium evidence for direct rain recharge to ground waters in the northern Kalahari. Nature $249,643-644$. 
. 
E.W. ANDERSON \& N.J. COX

A COMPARISON OF DIFFERENT INSTRUMENTS FOR MEASURING SOIL CREEP

ANN R.M. YOUNG

THE INFLUENCE OF DEBRIS MANTLES AND LOCAL CLIMATIC VARIATIONS ON SLOPE STABILITY NEAR WOLLONGONG, AUSTRALIA

A.C. IMESON

SLOPE DEPOSITS AND SEDIMENT SUPPLY IN A NEW ENGLAND DRAINAGE BASIN (AUSTRALIA)

W. SYMADER \& W. THOMAS

INTERPRETATION OF AVERAGE HEAVY METAL POLLUTION IN

FLOWING WATERS AND SEDIMENT BY MEANS OF HIERARCHICAL

GROUPING ANALYSIS USING TWO DIFFERENT ERROR INDICES

K. HEINE

RADIOCARBON CHRONOLOGY OF LATE QUATERNARY LAKES IN THE KALAHARI, , SOUTHERN AFRICA

I.D.L. FOSTER

SEASONAL SOLUTE BEHAVIOUR OF STORMFLOW IN A SMALL AGRICULTURAL CATCHMENT

R. HERRMANN

REGIONAL PATTERNS OF POLYCYCLIC AROMATIC HYDROCARBONS IN NE-BAVARIAN SNOW AND THEIR RELATIONSHIPS TO ANTHROPOGENIC INFLUENCE AND AIR FLOW

A.M. HARVEY

DISSECTED ALLUVIAL FANS IN SOUTHEAST SPAIN

P. MICHEL

LA VALLEE ALLUVIALE DU SENEGAL (AFRIQUE DE L'OUEST). RELATIONS GEOMORPHOLOGIE - SOLS - APTITUDES CULTURALES ET LEUR CARTOGRAPHIE AU 1/50 OO0 
The list of illustrations should contain titles (possibly abbreviated) pertaining to each illustration.

Manuscripts: typewritten, double-spaced, size of paper: $21-22 \times 28-30 \mathrm{~cm}$, written on one side only, $\operatorname{marg} 1 \mathrm{n}: 4 \mathrm{~cm}$.

Please avoid footnotes. If unavoidable they should be numbered in sequence.

since page proofs will not be provided, cross-references within the text should refer to sections, not pages.

References in the text:

Every reference to publications in the text should appear in the 11st of references. References in the text: AUrmon (year, page) or (AUrHOR year, page). Author's name in capital letters; page-nubers should be given wenever practicable; direct quotations should always be page-referenced.

List of references :

Arranged according to author's surname, and chronologically per author.

AUTHOR (year): Title of article. Journal or booktitle (for wult1-author books give editor, volume number (please underline), pages; publisher and city (for books only).

Example:

ZEUNBR, F.E. (1953): Das Problen der Pluvialzelten. Geologische Rundschau $41,241-253$.

The journal's title should be written out in full rather than abbreviated.

Tables and illustrations should be enclosed separately (stating name of author, abbreviated title of essay and indication of top of illustration). Numbering should be continuous, and separate for Tables, drawings (marked as Figures) and photographs (marked as Photos). Legends of sufficlent length, in the language of the paper and possibly in English, should be collected on a separate sheet (stating author's name and short title of paper).

For the rough draft of Iine drawings please observe the following guide-lines:

1. All figures and text wil be reduced in size $23 \%$.

2. The maximum size possible for line drawings is $27 \times 18.5 \mathrm{~cm}$ (after 23 reduction: $20.8 \times 14.2 \mathrm{~cm})$. If laxger formats are needed, please consult the Editorial office.

3. Line arawlings should be drafted with black India ink on white drawing paper; high quality prints are acceptable.

4. The final format for all Iine drawings 1111 be decided by the Editorial office. The authors may be asked to change their format. It is very important that the letter size in the line drawings be no less than 2 m.

5. Use bar scales on all 14 lustrations instead of numerical scales that must be changed with reduction.

Photographs are acceptable only when showing good contrast and intensity; sharp and glossy prints are required. Prints from existing half-tone illustrations cannot be accepted. Coloured 11 lustrations cannot be included usually unless financed by the authors.

No manuscript or figures $\$ 11$ be returned following publication. It is the author's responsibility to obtain written perwission to reproduce material which has appeared in another publication. 100 reprints free of charge. Additional reprints way be ordered on the form acocomanying the proofs.

\section{EDITORIAL OFFICE CATENA}

c/o Lehrstuhl für Pirysiache Cocorraphie und Landschaftebkologio

Technische Univereltut Braunschwolo

Langer Kamp $19 \mathrm{C}$

D 3300 BAAUNSCHWEIG /W. Germany

Telefon (0531) 391-2561

Fornschrelber: tu bewg 952526

Postfach der TU 3329

Individual lesues will be of varying length and will be grouped into continuously paginated volumes of $400-450$ pages.

Price of Vol. 5, 1978

Personal Subscribers

\section{Copyright by CATENA VEALAG}

Margot Rohdenburg M.A.

Brockenblick 8

D 3302 Cremlingen-Destedt/W. Germany.
U\$ $\$$ 43,50, ' DM $86,-$ U\$ $\$ 29,60$, DM 